\title{
Apparent Specific Dynamic Action of Food in the Fish Blennius pholis
}

\author{
O. Vahl* and J. Davenport
}

\author{
N.E.R.C. Unit of Marine Invertebrate Biology, Marine Science Laboratories, Menai Bridge, Gwynedd LL59 5EH, United \\ Kingdom
}

\begin{abstract}
Intertidal fish Blennius pholis L. were given rations of mussel flesh. After feeding, the oxygen consumption of the blennies increased rapidly and reached a maximum after $2-4 \mathrm{~h}$. It then decreased gradually, the time taken to return to prefeeding level increasing with increasing ration size. The loss of energy through apparent specific dynamic action (SDA) was closely related to the size of the ration and amounted to about $10 \%$ of the ingested energy. Apparent SDA reduces the Scope for activity significantly. The likely impact of SDA upon the feeding strategy of $B$. pholis exposed to salinity fluctuations is discussed.
\end{abstract}

\section{INTRODUCTION}

Ingestion of a meal gives rise to an increase in metabolic rate known as 'specific dynamic action (SDA) of the food consumed' (Kleiber, 1961). The biochemistry of SDA is incompletely understood, but the energy liberated is generally assumed to be largely a consequence of protein metabolism (Buttery and Annison, 1973). Energy requirements for absorption, digestion, transportation and deposition of food materials are presumed to be minimal. They are distinct from SDA, but difficult to separate experimentally; when the distinction is not made, the term apparent SDA is appropriate (Beamish, 1974).

In fish, the SDA causes the oxygen uptake to increase rapidly after feeding to reach a maximum and thereafter to decrease more or less regularly to prefeeding level (Averett, 1969; Muir and Nimi, 1972; Beamish, 1974). This increase will reduce the 'scope for activity", which in a fasting, nonswimming fish, is the difference between 'routine' and 'active' metabolic levels (Fry, 1957; Brett 1964, 1970, p. 541; Weatherley, 1972).

In the littoral Blennius pholis the scope for activity, and hence the capacity for foraging, is further reduced by increased metabolic demands associated with encountering low salinities (Davenport and Vahl,

- On leave from Institute of Biology and Geology, University of Tromsø, Norway.
1979), and by being a 'solitary' species (Gibson, 1967; 1968) which consumes energy in defending its home range (Wirtz and Davenport, 1976). Therefore, if the contributions to the oxygen demand by these processes are large in relation to the scope for activity, the feeding strategy of the blenny might to some extent be governed by the influence of SDA on the scope for activity.

The present paper investigates the extent and duration of SDA in Blennius pholis, and discusses the likely impact of SDA upon the feeding strategy of blennies in a tidal habitat exposed to salinity fluctuations.

\section{MATERIALS AND METHODS}

\section{Collection and Maintenance}

Blennies Blennius pholis L. were mainly collected from the intertidal zone of the rocky west coast of Anglesey (U.K.) between Aberffraw and Rhosneigr. Some individuals were taken from the shore of the Menai Strait beneath the northern end of Telford Suspension Bridge. Blennies were collected from pools, crevices and muddy gravel beneath stones. In pools, they were caught by the use of the anaestetic quinaldine (Gibson, 1967a). The fish ranged in wet weight from 14.5 to $16.7 \mathrm{~g}$. To obtain arrythmic individuals, the blennies were held in the laboratory seawater system at $10^{\circ} \mathrm{C}$ under constant illumination (Gibson, 
$1967 \mathrm{bj}$. They were starved for two weeks before use in experiments, all performed at $10^{\circ} \mathrm{C}$ in constant light.

\section{Respirometry and Feeding}

For oxygen consumption measurements we used the flow respirometer technique described by Davenport and Vahl (1979). Two departures from this basic technique were made. Firstly all measurements were made in full seawater ( $34 \%$ S). Secondly, the lid of the experimental vessel was modified to allow feeding during oxygen consumption determinations: A hole was drilled in the lid. The hole was guarded on the upper surface by a rubber teat containing a plastic rod. On the lower surface of the lid is a bell-shaped perspex chamber, closed by a perspex sheet attached to the chamber by a smear of silicone grease. To allow feeding, teat and chamber were filled with seawater, a preweighed meal of mussel (Mytilus edulis) mantle added, and the perspex sheet applied to seal the chamber; care was taken to ensure that no air bubbles were trapped. The surface of lid and chamber were then washed to remove food traces and the lid was screwed on to the experimental vessel. To feed the fish the plastic rod was pushed into the chamber by depression of the rubber teat; the perspex sheet was dislodged and the meal fell into the experimental chamber. The perspex sheet was attached to the lid by a short length of plastic coated wire so that it did not fall upon the fish. The ration ranged from 1.8 to $4.5 \%$ of body weight (mean $=3 \%$ of body weight).

\section{Experimental Sequence}

(1) A blenny was placed in the $250 \mathrm{ml}$ experimental vessel and a food laden lid applied. (2) The oxygen uptake of the fish was monitored; after it had settled down somewhat, the flow rate through the experimental vessel was adjusted so that the fish removed 10-15\% of the oxygen from the seawater flowing over it. (3) When the fish had shown no systematic increase or decrease in oxygen uptake for $3 h$, food was offered. The timing of actual feeding was carefully noted on the oxygen tension trace and the fish's oxygen consumption was monitored for a further $24 \mathrm{~h}$ after feeding. (4) The fish was removed from the respirometer and weighed.

In a bottom dwelling fish like the blenny it is difficult to determine the 'active metabolism' which is measured as the maximum sustained oxygen uptake (Fry, 1957; Weathericy, 1972). However, after being introduced into the experimental chamber the blennies showed a considerable increase in oxygen uptake; this gradually abated and the oxygen uptake reached a steady level in 1 to $3 \mathrm{~h}$ after the start of the experiment. The maximum oxygen uptake of the fish after it was introduced into the chamber was taken to correspond to active metabolism. The steady pre-feeding level of oxygen uptake by the blenny was taken as the routine metabolism' - which includes basal metabolism and spontaneous activity (Fry, 1957). The difference between routine level and the level at any time after feeding was taken as the apparent SDA.

\section{RESULTS}

Of the 10 experimental fish, six fed successfully while two only reacted slightly to the food, and two unsuccessfully chased the food for several minutes before becoming quiet again.

After feeding successfully the oxygen consumption of the six blennies (Fig. 1) increased rapidly to reach a maximum after $2-4 \mathrm{~h}$ (mean $=2.8,95 \%$ confidence interval: $1.7-3.8$ ). It then decreased gradually, return-

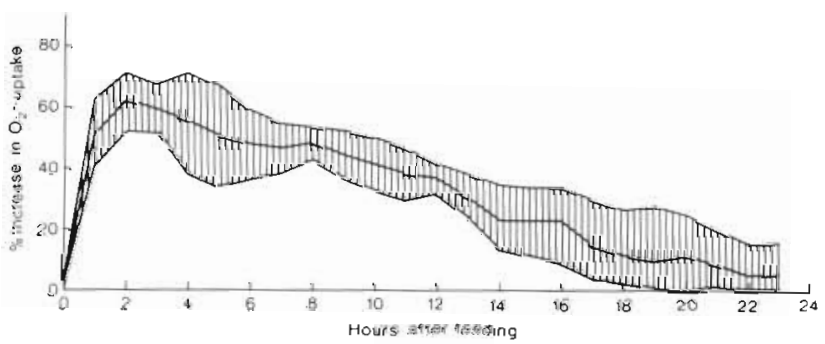

Fig. 1. Blennius pholis. Variations in oxygen consumption after feeding. Mean and $95 \%$ confidence limits of the mean (shaded areas). Assymmetrical confidence limits are caused by arcsin $V p$ transformation used when dealing with proportions

ing to pre-feeding level after more than $20 \mathrm{~h}$. A significant correlation was neither found between ration size and time to reach maximum level of oxygen consumption, nor between ration size and that level itself ( $r=-0.293$ and $r=0.392$ respectively, $D F=4, P>$ 0.1 ). The time taken to subside to within $10 \%$ of the pre-feeding level showed a significant correlation with ration size $(r=0.832, D F=4,0.05>P>0.02)$ (Fig. 2).

Four blennies were offered food without subsequently ingesting the ration. Also in these cases oxygen consumption increased, but it abated to pre-feeding level within $1 \mathrm{~h}$. Two of the blennies unsuccessfully chased the food offered. This caused the oxygen consumption to rise sharply and to reach a maximum of 35 and $75 \%$ above pre-feeding level. In the two fishes which did not try to take the food, little reaction could be seen, except a few 'gulping' movements of mouth and opercula. In these cases the maximum increase above pre-feeding level were 18 and $6 \%$, respectively. 


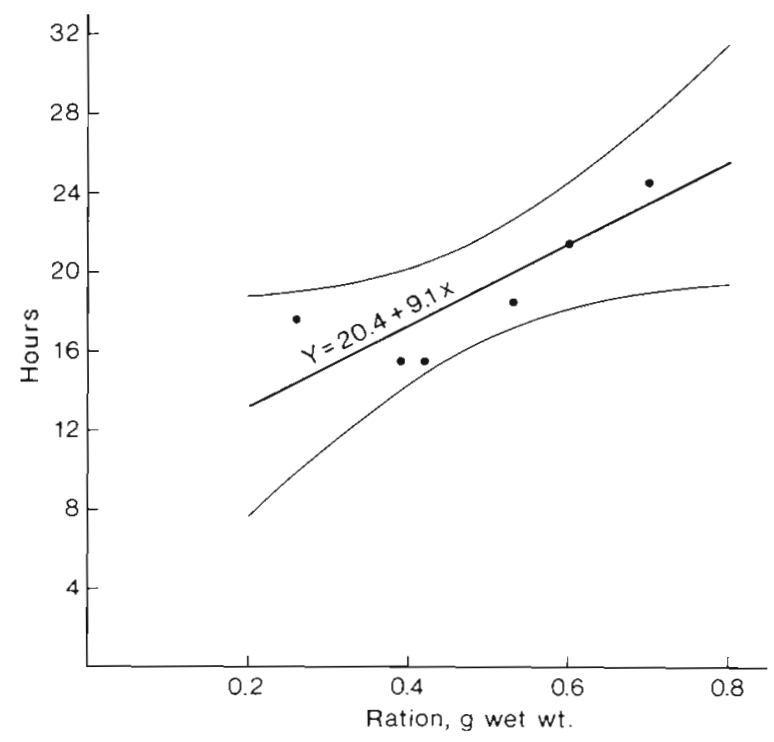

Fig. 2. Blennius pholis. Relation between ration size and time required for the SDA level to subside within $10 \%$ of prefeeding level. Observed values, regression and $95 \%$ confidence limits of mean

To obtain a measure of the total loss of energy through apparent SDA, the curves of oxygen consumption above pre-feeding level for each fish were traced on paper. The area under the curves were cut out and weighed. These weights were converted into an equivalent amount of oxygen consumed by the blennies above pre-feeding level from the time of feeding until the effect of feeding had disappeared. It appears that there is a strong correlation between the size of the ration and the total apparent SDA $(r=0.901, D F=5$, $0.01>P>0.005$ ) (Fig. 3). The correlation coefficient of 0.9 implies that $0.9^{2} \times 100=81 \%$ of the variation in total apparent SDA is accounted for by the regression. However, the range of ration size is comparatively small (Fig. 3)., therefore the curve in Figure 1 gives the

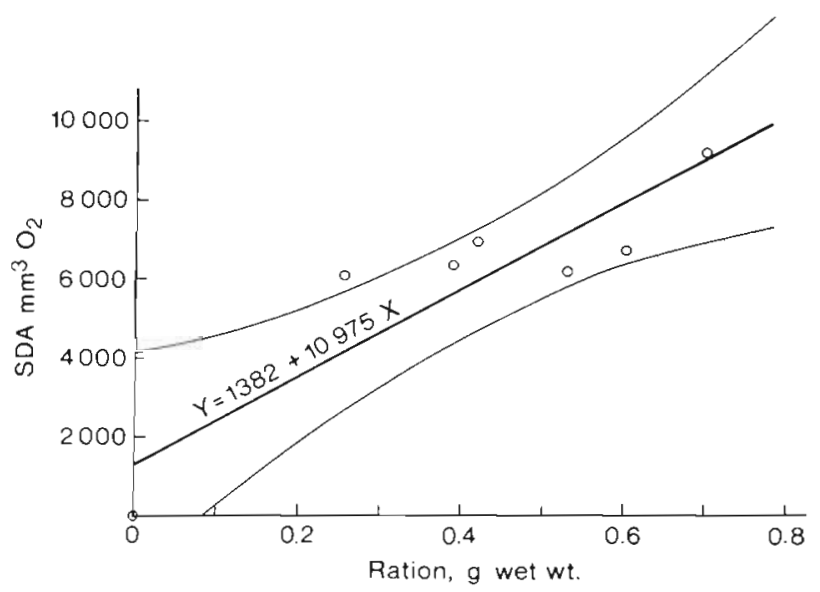

Fig. 3. Blennius pholis. Relation between ration size and todal SDA. Observed values and $95 \%$ confidence limits of mean mean of apparent SDA for the six fish that fed successfully.

The 'active metabolism' was taken as the maximum oxygen consumption observed after introducing the blennies into the experimental chamber. It appears that the 'active' level so defined is about twice the 'routine' level $($ mean $=2.16 \times$ routine level, $95 \%$ confidence interval: $1.90 \times$ routine level $-2.42 \times$ routine level).

\section{DISCUSSION}

As in other studies of SDA in fish (Averett, 1969; Muir and Niimi, 1972; Beamish, 1974), the oxygen consumption after feeding increased abruptly to reach a maximum, thereafter decreasing to the pre-feeding level. The time to reach pre-feeding level increases with increasing ration. Part of the elevated oxygen consumption in the first hour after feeding (Fig. 1) was caused by physical activity as the two individuals which unsuccessfully chased the food showed an increase in oxygen uptake of 35 and $75 \%$, respectively. In the present study, no correlation between ration size and time to reach maximum SDA could be demonstrated. Beamish (1974) found a significant increase with ration size in largemouth bass, wheras Muir and Niimi (1972) found no difference.

Assuming the biochemical composition of the mussels analyzed by Williams (1969) to hold for the mussels used in the present experiment, the calorific content can be estimated to about $750 \mathrm{gcal} \mathrm{g}^{-1}$ wet weight. Assuming further an oxycalorific coefficient of $4.8 \mathrm{gcal}$ $\mathrm{ml}^{-1} \mathrm{O}_{2}$ (Kleiber, 1961), the total apparent calorigenic effect (Kleiber, 1961) of mussel flesh is $9.7 \%(95 \%$ confidence interval: $7.5-11.9 \%$ ). This seems somewhat lower than the 16-19\% found for the white flesh of skipjack tuna fed to aholehole (Muir and Niimi, 1972), but is probably not significantly different from the $14 \%$ for emerald shiners fed to largemouth bass (Beamish, 1974).

The high oxygen consumption observed after introducing the blennies into the experimental chamber was probably due to the handling of the fish. After this effect had abated, the highest oxygen consumption was found $2-4 \mathrm{~h}$ after feeding. At this point the scope for activity is at a minimum and was reduced by an average of $50 \%$ by a mean ration of $3 \%$ of body weight (Fig. 1). Muir and Niimi (1972) found that, at maximum ration, the scope for activity in aholehole decreased by less than $50 \%$, whereas Beamish's results $(1970,1974)$ can be combined to show that, in a $150 \mathrm{~g}$ largemouth bass, a maximum ration ( $8 \%$ of body weight) gives a maximum SDA equal to half the scope for activity.

The time for the oxygen consumption to subside to 
the pre-feeding level increases with ration size in aholehole (Muir and Niimi, 1972), in largemouth bass (Beamish, 1974), and in the blenny (Fig. 2). Since the total energy lost as SDA is closely related to ration size (Beamish, 1974; present study Fig. 3) the maximum elevation of oxygen consumption might also increase with ration. To what extent this will be the case depends on the duration of the SDA effect. In aholehole and largemouth bass the maximum oxygen uptake after feeding increases with ration size (Muir and Niimi, 1972; Beamish, 1974) so that in these species, the increase in duration of the effect does not completely compensate for the increase in total SDA. In the blenny such an increase in the maximum level could not be demonstrated.

The blenny ingests and absorbs new meals before previous meals are completely processed (Crawford, 1977) and therefore the effects of repeated meals on SDA, and thus on oxygen consumption, are cumulative. In a fish where the difference between routine and active metabolism is of the same magnitude as the

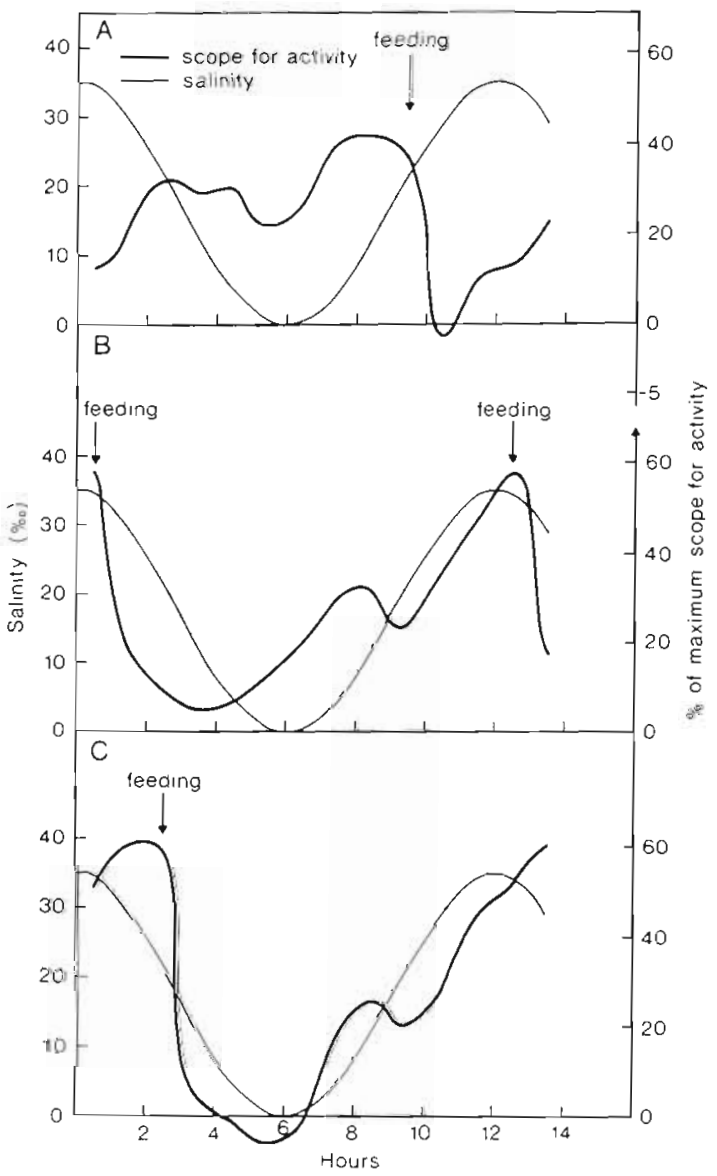

Fig. 4. Blennius pholis. Combined effects on scope for activity of varying salinities; $3 \%$ ration every $12 \mathrm{~h}$ at different times. Effect on oxygen consumption of varying salinities from Davenport and Vahl (1979) maximum SDA the metabolic demands might thus exceed the scope for aerobic metabolism when large meals are taken at short intervals. Accordingly, the food intake might be influenced by the calorigenic effect of the food.

In Blennius pholis this appears to be the case. Crawford (1977) found that starved blennies of $15.3 \mathrm{~g}$ would take a maximum meal of $9.8 \%$ of Mytilus flesh but Wallace (1973) established that, at $10{ }^{\circ} \mathrm{C}$, a blenny of the same size would take $0.46 \mathrm{~g}$ or $3 \%$ of body weight when fed to satiation twice a day. Wallace (pers. comm.) found that the blennies usually ate the same amount in both meals.

In its littoral habitat the blenny is required to expend energy in meeting the demands of both SDA and increased metabolism with fluctuating environmental salinity levels (Davenport and Vahl, 1979). The energy demands of these two processes are such that the ingestion of a single large meal would need to be timed fairly precisely if a high scope for activity, and consequently, 'scope for feeding' were to be maintained at subsequent periods of food availability (Fig. 4). Less precise timing would be needed to maximize food intake if the blenny started to feed on small food items during the flood tide and continued to top up the foregut until the scope for activity and feeding was reduced to a low level by SDA. The latter strategy seems to be adopted by the blenny because the species is a browser, feeding predominantly upon barnacle cirri and small crustaceans (Quasim, 1957), even though it is capable of taking large rations (Crawford, 1977).

Acknowledgement. Thanks are due to The Norwegian Research Counsil for Science and the Humanities for financial support to O.V.

\section{LITERATURE CITED}

Averett, R. C. (1969). Influence of temperature on energy and material utilization by juvenile coho salmon. Ph.D. thesis, Oregon State University.

Beamish, F. W. H. (1970). Oxygen consumption of largemouth bass, Micropterus salmonides, in relation to swimming speed and temperature. Can. J. Zool., 48, 1221-1228.

Beamish, F. W. H. (1974). Apparent specific dynamic action of largemouth bass, Micropterus salmonides. J. Fish. Res. Bd Can., 31, 1763-1769.

Brett, J. R. (1964). The respiratory metabolism and swimming performance of young sockeye salmon. J. Fish. Res. Bd Can., 21, 1183-1226.

Brett, J. R. (1970). Temperature: animals: fishes. In O. Kinne (Ed.), Marine Ecology, Vol. I, Environmental Factors, Part 1. Wiley, London. pp. 515-560.

Buttery, P. J. and Annison, E. F. (1973). Consideration of the efficiency of amino acid and protein metabolism in animals. In J. G. W. Jones (Ed.), The Biological Efficiency of 
Protein Production. Cambridge University Press, London. pp. 141-171.

Crawford, C. (1977). Food consumption and digestion in Blennius pholis. M.Sc. thesis, University College of North Wales, Bangor

Davenport, J. and Vahl, O. (1979). Responses of the fish Blennius pholis to fluctuating salinities. Mar. Ecol. Prog. Ser., 1, 101-107.

Fry, F. E. J. (1957). The aquatic respiration of fish. In M. E. Brown (Ed.), The Physiology of Fishes, Vol. 1. Academic Press, New York. pp. 1-63.

Gibson, R. N. (1967a). The use of the anaestetic quinaldine in fish ecology. J. Anim. Ecol., 36, 295-301.

Gibson, R. N. (1967b). Experiments of the tidal rhythm of Blennius pholis. J. mar. biol. Ass. U.K., 47, 97-111.

Gibson, R. N. (1968). The agonistic behaviour of juvenile Blennius pholis. Behaviour, 30, 192-217.

Kleiber, M. (1961). The Fire of Life, An introduction to animal energetics, Wiley, New York.
Muir, B. S. and Niimi, A. J. (1970). Oxygen consumption of the euryhaline fish aholehole (Kuhlia sandvicensis) with reference to salinity, swimming, and food consumption. $J$. Fish. Res. Bd Can., 29, 57-77.

Quasim, S. Z. (1957). The biology of Blennius pholis (L.) (Teleostei). Proc, zool. Soc. Lond., 128, 161-208.

Vahl, O. (1979). An hypothesis on the control of food intake in fish. Aquaculture, 17, 221-229.

Wallace, J. C. (1973). Observations on the relationship between the food consumption and metabolic rate of Blennius pholis L. Comp. Biochem. Physiol., 45A, 293-306.

Weatherley, A. H. (1972). Growth and Ecology of Fish Populations, Academic Press, London.

Williams, C. S. (1969). The effect of Mytilicola intestinalis on the biochemical composition of mussels. J. mar. biol. Ass. U.K., 49, 161-173

Wirtz, P. and Davenport, J. (1976). Increased oxygen consumption in blennies (Blennius pholis L.) exposed to their mirror images. J. Fish Biol., 9, 67-74.

This paper was presented by Professor T. M. Fenchel; it was accepted for printing on August 8, 1979. 